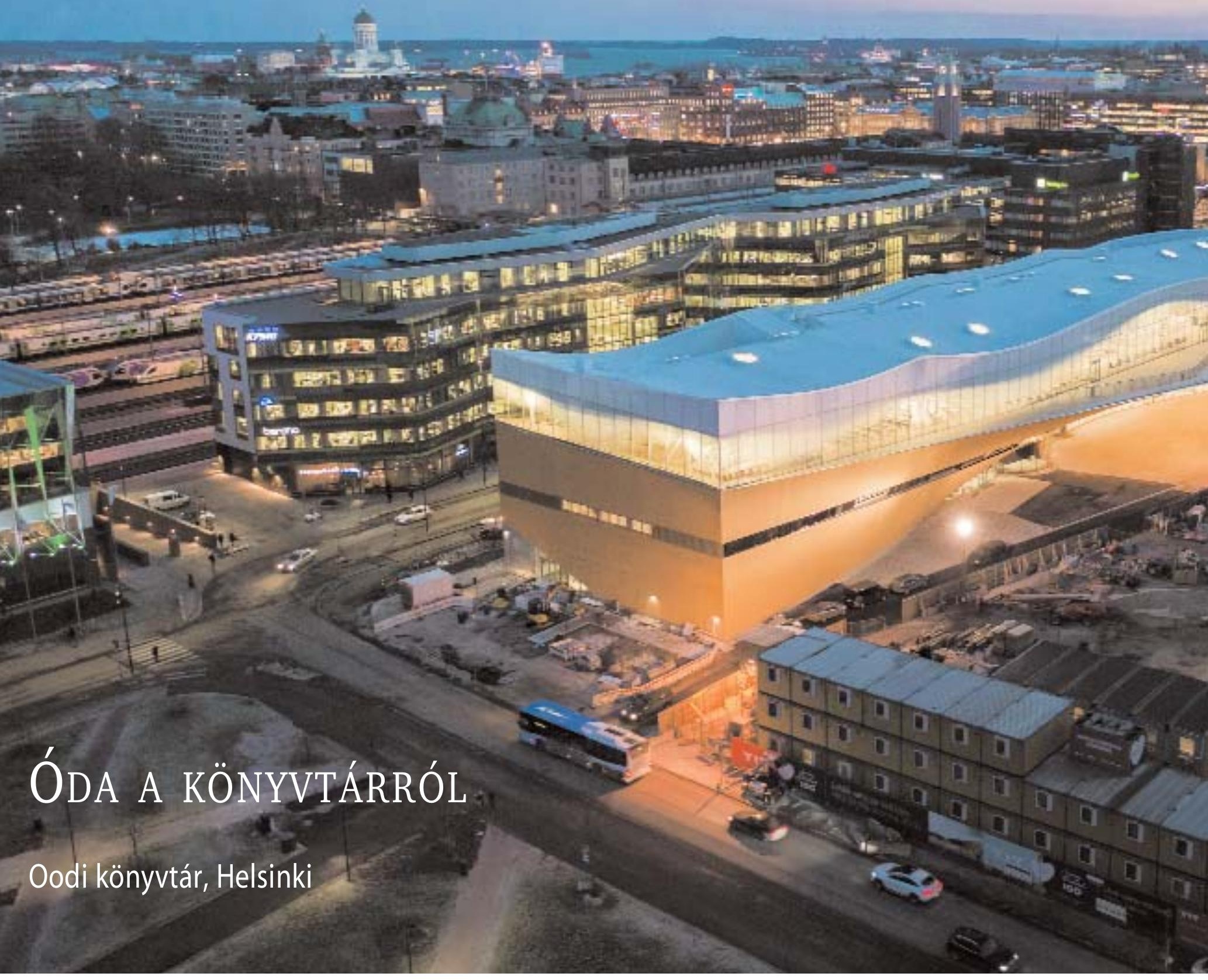

A Helsinki Zenei Központ felöl elénk táruló látvány: az Oodi, mögötte egy irodaház, a Finn Nemzeti Színház, a Helsinki Katedrális és a tenger
A finnek számára a könyvtár a mindennapi élet szerves része. Így azután természetes, hogy az ország századik születésnapjára egy gyönyörü, új könyvtárral ajándékozta meg magát. [1] A Finnországban épült új központi könyvtár neve Oodi lett, amely magyarul annyit tesz: Óda. A könyvtár Helsinki szívében fekszik, szemben a parlamenttel, tőle jobbra a Helsinki Zenei Központ, a Musiikkitalo található, balra a Kiasma Kortárs Múvészeti Múzeum, háta mögött meg a központi pályaudvar.

\section{Az építészek}

Az Oodi a könyvtárak új korszakát képviseli. A pályázaton kiválasztott [2] tervezők - a finn Arkkitehtitoimisto ALA (ALA Architects) munkatársai - három szintre osz- tották a könyvtárat: az aktív földszintre, a békés felső szintre és a köztük elhelyezkedő zártabb, speciális feladatokat ellátóra. Az épület íves, alul hídszerü, felül felhőszerű alakja vonzza a látogatót, hogy használja a könyvtárat, a szolgáltatásokat a híd íve alatt és fölött; az épületen kívül és belül. Az így létrejött épület szerves részévé vált Helsinki belvárosának. Jellemző a finn fővárosra, hogy a belváros közepén kényelmesen elfért az új épület, és előtte is, mellette is maradt még bőven szabad tér.

„A városlakók építészeti álmaira szerettünk volna válaszolni az Oodi terveivel. S ahogy haladtunk előre, a terv elkezdett meglepően ellenállhatatlanná, ugyanakkor különösen észszerű épületté válni, és a részek összegé- 


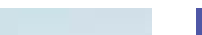

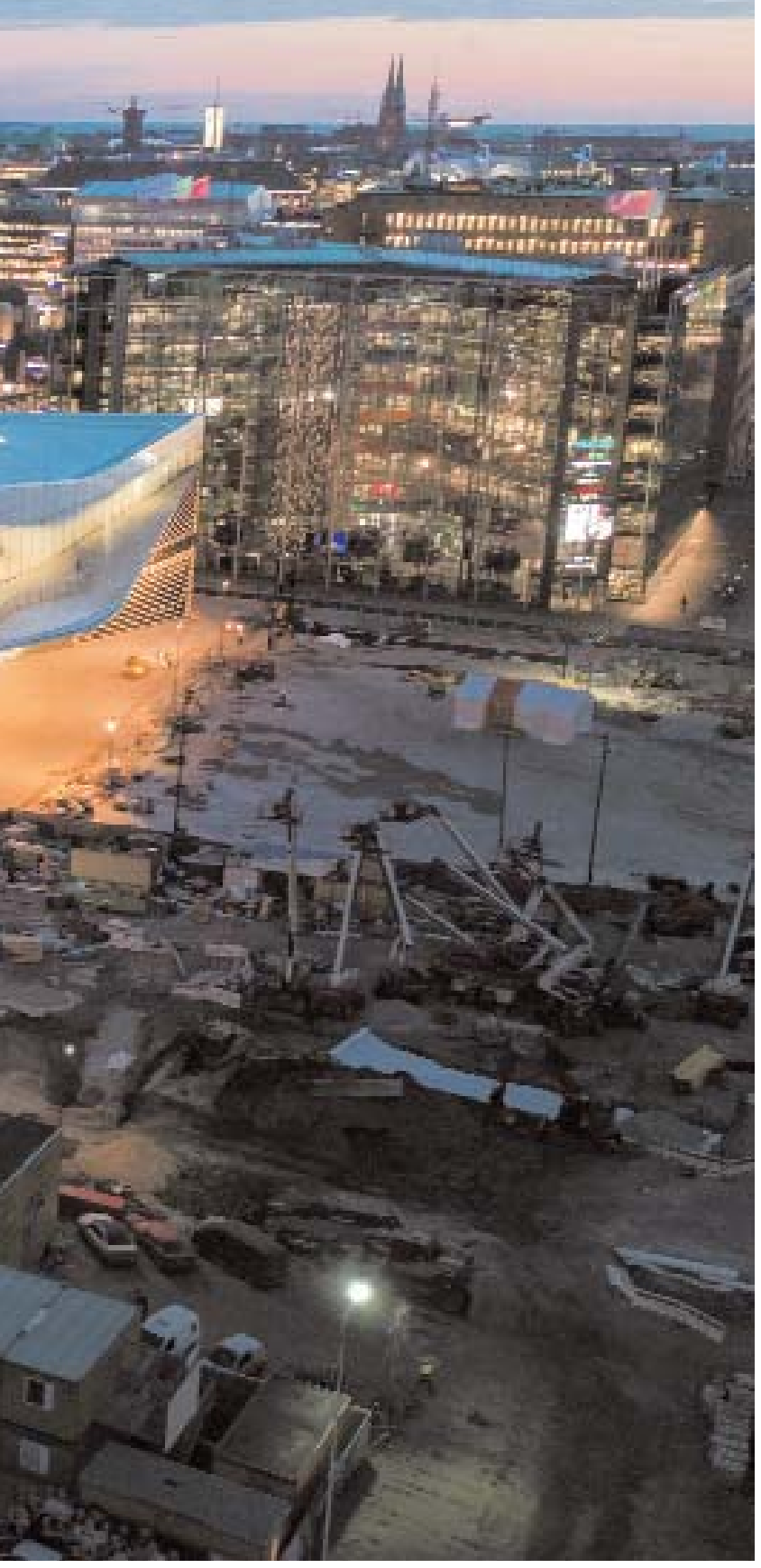

nél nagyobb egésszé összeállni. Szerintünk a kész épület megfelel a verseny kiírásának, és egyben az eredeti ötletünket is kiválóan tükrözi. Alig bírtuk kivárni, hogy a városlakók birtokba vegyék az épületet" - mesélik a tervezők, az Arkkitehtitoimisto ALA tulajdonosai, Juho Grönholm, Antti Nousjoki és Samuli Woolston építészek. „Mit várunk el ma egy könyvtártól? A koncepciónk szerint egy olyan nagyvárosi, polgári lakást képzeltünk el, amiben van nappali, konyha és dolgozószoba. Hazánkban a könyvtár szinte szent helynek számít, innen jött a kapcsolat az otthonnal. Szerintünk nem az a fo feladata, hogy bármit kikölcsönözzünk onnan, hanem inkább találkozóhelynek kell lennie. Az Oodi egy polgári lakás, ahol akár dobolni is lehet, és amelynek ,polgári erkélyéről' koncentráltan látszik a demokrácia és a kultúra - a szemben fekvő parlament és kétoldalt a zenei központ és a múzeum. Az Oodiban felszállunk a könyvmennyországba" - teszi hozzá Juho Grönholm.

\section{A könyvtár}

Az épületnek három bejárata van: az első délre néz, a fópályaudvar irányába, a második nyugatra, a parlament és Helsinki egyik központi tere, a Kansalaistori (Polgárok tere) irányába, a harmadik pedig, az északkeleti sarokban főként a mozi és a családi könyvtár látogatói számára nyílik.

A könyvtár és a parlament épülete között fekvő Kansalaistori (Polgárok tere) vizuálisan folytatódik az épület földszintjén a bejárati front üvegfalának köszönhetően. Az épület homlokzatának faborítása pedig a földszint mennyezetén fut tovább. Ez a megoldás leheto"vé teszi a nyitott, tartópillér nélküli belső tér átláthatóságát. (Eszünkbe juthat Toyo Ito szendai Médiatékája. [3]) A földszint nagy része egyterű, itt kapott helyet a többfunkciós nagy előadóterem, több kisebb rendezvénytér, kiállítóterek, találkozóhelyek, kávézó, étterem, látványkonyha, és a többitől elkülönülő moziterem.

A legfölső szint a „könyvmennyország”, ahol egy hatalmas, hullámzó felhő alól nézhetünk ki a környező világra. Ezt a felhőhatást egyrészt a hullámos fehér menynyezet, másrészt az ablaküveget borító fehér pöttyök, a „hópelyhek” adják, amelyek fölülről lefelé haladva egyre ritkábban pöttyözik az üveget. Így azután az üvegfal teteje teljesen fehér, az alsó fele pedig teljesen átlátszó, ezzel egyben a nyári árnyékolást is biztosítja. Szubtrópusi élő fák (fekete olajfa, bucida buceras) teszik még barátságosabbá, otthonosabbá, élőbbé a teret. A nyugodt könyvtári légkör vonz az olvasásra, tanulásra, meditálásra, vagy egyszerűen csak az élet élvezetére. Itt található még a gyermekkönyvtár is, ahol különleges meseszoba és előadótér is várja a legfiatalabb látogatókat. A fölső szinten van még egy hatalmas erkély, amely nyugatra néz a parlament és a Kansalaistori (Polgárok tere) felé. Innen kapta a nevét is: Kansalaisparveke (Polgárok erkélye), jelképezve a könyvtár polgári otthon jellegét.

A középső szint a „padlás” nevet kapta. Ennek oka részben a kisebb belmagasság, részben az itt húzódó vasbeton híd, amely összetartja az épület szerkezetét. Az ívelt fahomlokzat az épület belsejében tükröződik a szint középső, nyitott részén elhelyezett „üldögélőlépcsőn”, amelyet középen, a híd alatt alakítottak ki, itt mód van egyedül vagy kisebb csoportokban olvasni, tanulni, vagy épp társasjátékozni. Ezen a szinten a hagyományos könyvtár fogalmát kibővítve sokféle dolgot müvelhetünk. Többek közt lehet csoportos megbeszéléseket tartani, zenélni, filmet készíteni, szerkeszteni, varrni, főzni,
Épít és z:

\section{Arkkitehti-}

\section{toimisto ALA}

\section{Irodalom / References}

[1] Haavisto, Tuula: „A Dream Come True of Citizens - the New Helsinki Central Library",

in Diane Koen (ed): Library Design for the 21st Century: Collaborative Strategies to Ensure Success, Berlin, Boston: De Gruyter 2018, pp 203-213, DOl: <https://doi.org/10.15 15/9783110617535-015> [utolsó belépés: 2019-05-22].

[2] Burián, Gergő: „Ahogy a finnek csinálják.. - Elkészültek a Helsinki Központi Könyvtár tervpályázat második fordulós tervei", Metszet, Vol 4, No 4 (2013/4), pp 62-63. [3] Gutai, Mátyás: „Térgörbe - Tajcsung Nemzeti Színház", Metszet, Vol 6, No 3 (2015/3), pp 20-23. 


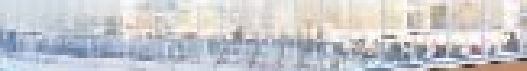

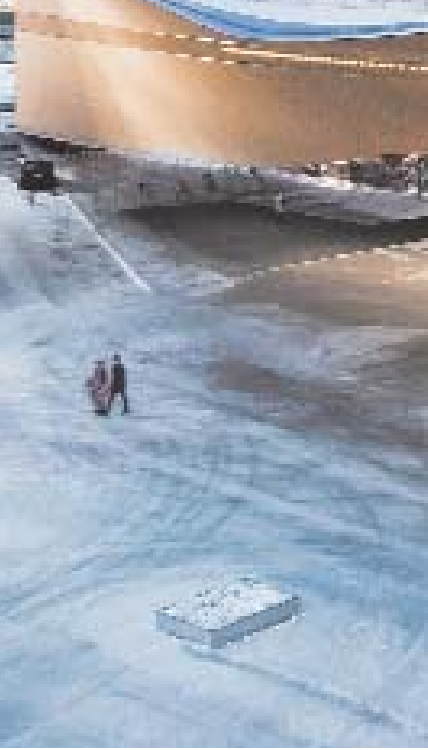

A Polgárok tere az üvegfalon át kapcsolódik a könyvtár fogadószintjéhez

\section{Metszet}

1. Gyerekvilág

2. Családi részleg

3. Kávézó

4. Kiszolgálópult

5. Ismeretterjesztő könyvek

6. Újságok

7. Kistermek

8. Tantermek

9. Ülölépcsők

10. Kiszolgálóterek

Alaprajz

1. Nézőtér

2. Vetitő

3. Kiszolgálóterek

4. Többfunkciós terem légtere

5. Kiállitótér nyomtatni, akár plakátot is, 3D-ben is. De mód van egyedül elvonulni alkotni, tanulni vagy elmélkedni a csöndes szobákba.

A szint végén található a „Kocka”, amely attól különleges, hogy „okos falak” határolják. A finn fejlesztésű, az alapesetben tejüvegnek tűnő falak számítógép-vezérléssel világítanak, képeket mutatnak. A mozgatható falak segítségével az összességében 100 négyzetméteres tér igény szerint részekre is osztható. A Kocka digitális művészeti galériának vagy virtuális tanteremnek is alkalmas.

$\mathrm{Az}$ irodák minimális helyet foglalnak el az épületben, a raktárak, könyvosztályozók pedig az alagsorban van-

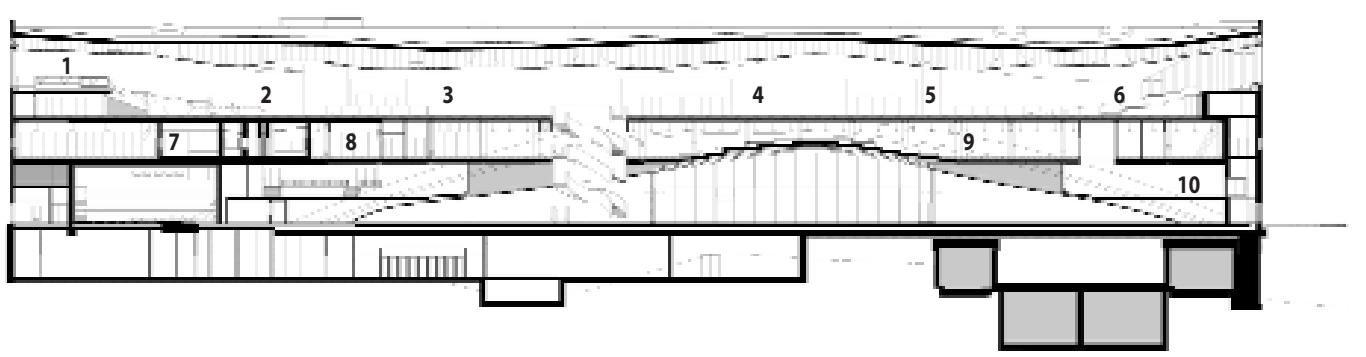




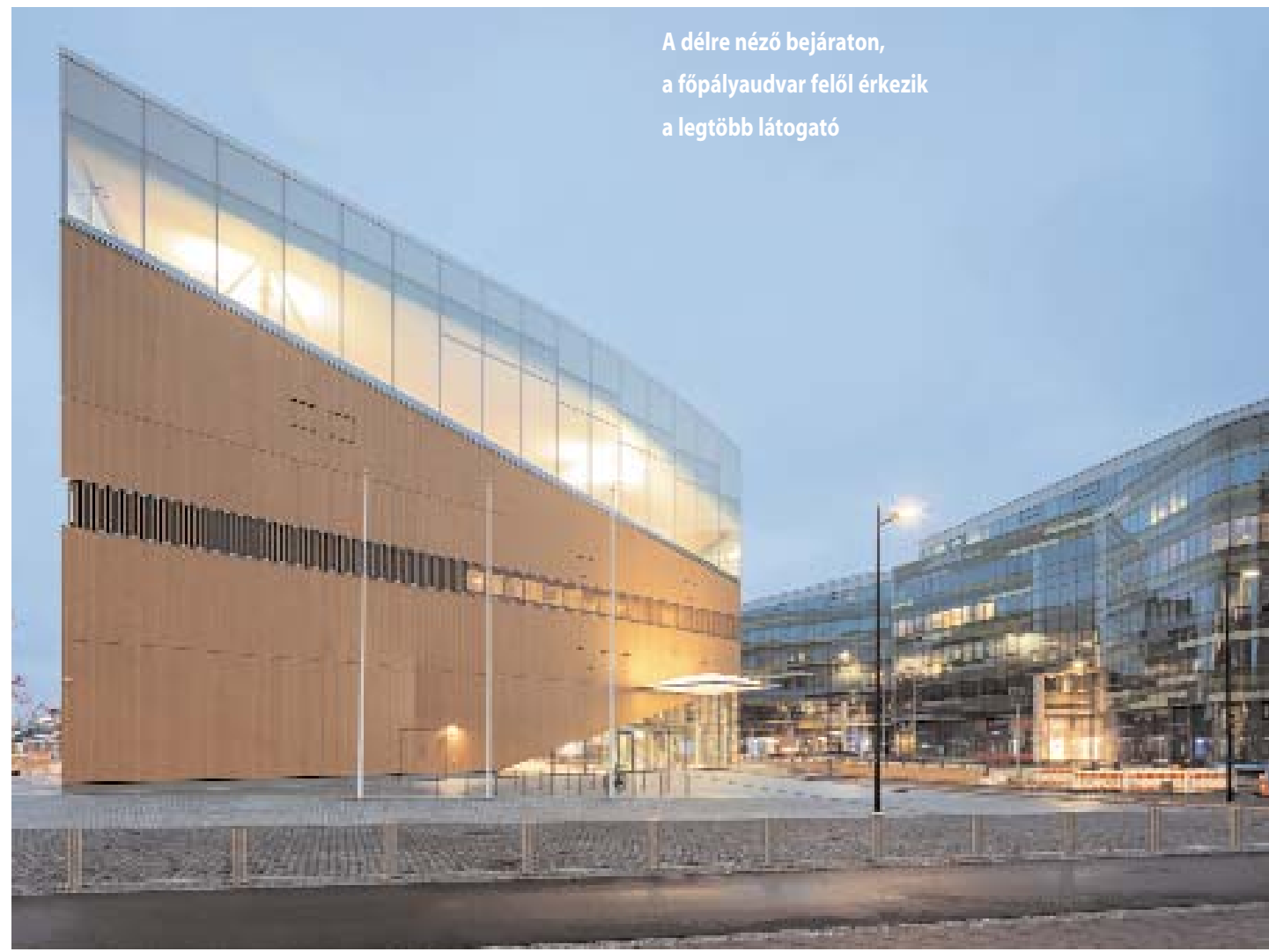

nak. Sőt, a raktárak egy része az eddigi központi könyvtárban, Pasilában maradt.

A könyvtár a hét minden napján várja a látogatókat, naponta akár 10000 főt is el tud látni, az egész évre tervezett látogatószám pedig 2,5 millió, ez amúgy közel a fele Finnország lakosságának. A könyvtári szolgáltatások ingyenesek, mint az egész országban, csak a plusz-

\section{A lucfenyö boritású külsó} homlokzat a földszint mennyezetén át folytatódik tovább szolgáltatásokért kell fizetni, így például a terembérlésért.

Az új trendnek megfelelően a mosdók koedukáltak, a legnagyobb az alagsorban van, amíg több kisebb a felsőbb szinteken. Az épület teljes egészében akadálymentes, mind a mozgássérültek, mind a látássérültek számára.

Építész: Arkkitehtitoimisto ALA (ALA Architects)

Megrendelő: Helsinki városa Üzemeltető: Helsinki Városi Könyvtár

Építészek a pályázat során: Juho Grönholm, Antti Nousjoki, Janne Teräsvirta és Samuli Woolston

\section{Munkatársak: Aleksi}

Niemeläinen, Jussi Vuori, Erica Österlund, Willem Barendregt, Martin Genet, Vladimir Ilic, Tiina Liisa Juuti, Julius Kekoni, Auvo Lindroos, Pekka Sivula, Pekka Tainio, Jyri Tartia

\section{Építészek a megvalósulás} során: Juho Grönholm, Antti Nousjoki, Janne Teräsvirta és Samuli Woolston

Munkatársak: Niklas Mahlberg, Jussi Vuori, Tuulikki Tanska, Tom Stevens, Nea Tuominen, Pauliina Rossi, Anna Juhola, Miguel Silva, Heikki Ruoho, Mirja Sillanpää, Michal Bala, Marina Diaz Garcia, Jyri Eskola, Zuzana Hejtmankova, Harri Humppi, Mette Kahlos, Anniina Kortemaa, Felix Laitinen, Malgorzata Mutkowska, T. K. Justin Ng, Marlene Oberli-Räihä, Olli Parviainen, Alicia Pena Gomez, Anton Pramstrahler, Jack Prendergast, Akanksha Rathi, Niina Rinkinen, Mikael Rupponen és Pekka Sivula

Épületgépészet: Arup (pályázat), Ramboll Finland (megvalósulás)

Látványterv: VIZarch

Elektromosság: Rejlers

Földmérés: Sipti Infra

Akusztika: Helimäki Akustikot

Színháztechnika: Granlund

BIM-koordinátor: Gravicon

Túzvédelem: Palotekninen insinööritoimisto Markku Kauriala Közlekedéstervezés: Pöyry Finland 


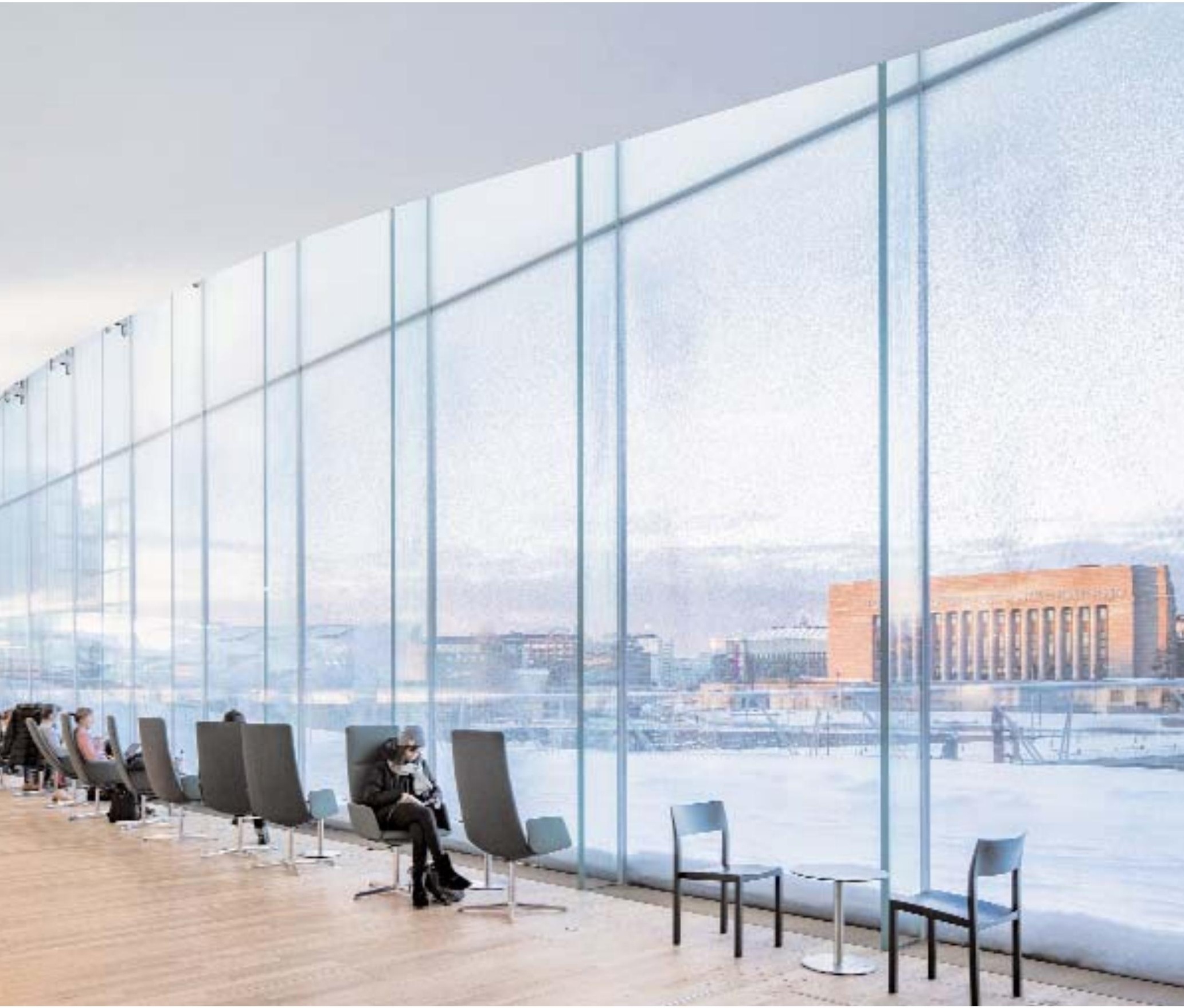

\section{A parlament a könyvmennyország felöl. Az üvegfalat fehér pöttyök, "hópelyhek" díszítik, föntröl lefelé haladva egyre ritkábban a látvány mellett a nyári hővédelemben van szerepük}

\section{Tervezési és kivitelezési bravúr}

Az épület jellegéből adódó kihívásokat - mint az eltérő szerepű három szint, a pillérmentes földszint, a kinti nyílt tér és a külső faburkolat zökkenőmentes folytatása a földszinten és maga a hullámszerü tető - egyetlen huszárvágással oldották meg a tervezők. Ez pedig a „híd”: két 100 méternél hosszabb fesztávolságú acélgerenda íve, és az azokat tartó acélszerkezet. Az acélíveket maszszív, megerősített vasbeton födém tartja össze. Ennek az innovatív megoldásnak köszönhető a földszinti aulában a tartópillérek nélküli rugalmas, szabad belső térkialakítás. A fölső szint hullámos födémét és az épület tömegéből kiálló második emeleti erkélyt aszimmetrikusan tartja az acél hídra terhelt másodlagos acélszerkezet. A tervezők által kiválasztott szerkezeti megoldásoknak kö- szönhetően az Oodi nemcsak a jelenlegi, hanem a jövőbeli könyvtári feladatoknak is megfelel.

Az Oodi külső faburkolata és az abból folyamatosan átmenő földszinti mennyezetburkolat a helyi éghajlati viszonyokra figyelve és helyi anyagokból készült. A burkolat előregyártott elemekből áll, amelyhez $33 \mathrm{~mm}$ vastag kiváló minőségű finn közönséges lucfenyőt (picea abies) használtak. A borítás a hajlított felület miatt algoritmussal támogatott parametrikus 3D-s tervezővel készült. A homlokzat az idő múlásával egyre sötétebb tónust vesz majd föl.

\section{Energetika}

Az épület közel nulla energiaigényú (nZEB), A osztályú, az energiafelhasználás kevesebb mint $90 \mathrm{kWh} /\left(\mathrm{m}^{2} \mathrm{a}\right)$. 


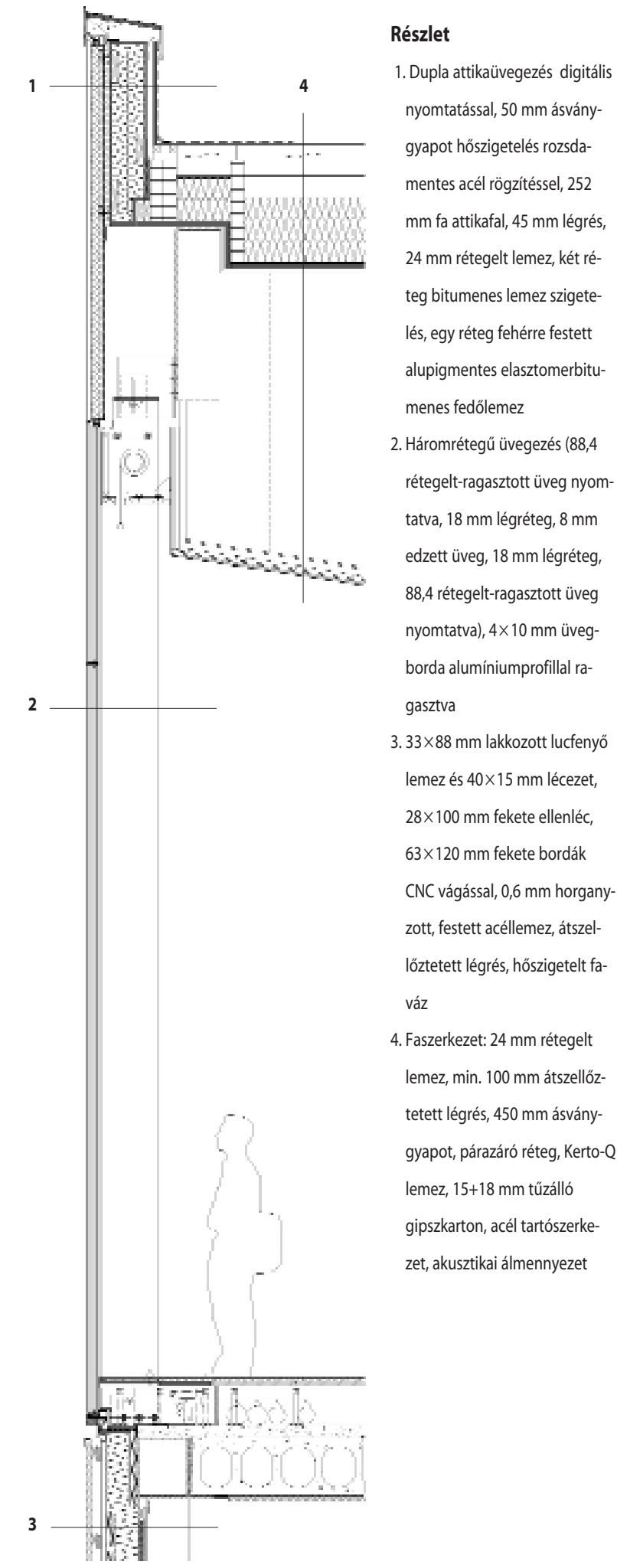

Sok más mellett a hatékonyság egyik fó forrása az épület faburkolata. Az épületinformációs modellezést (BIM) mind az építészeti, mind az egyéb mérnöki tervezés során használták, valamint a formatervezés kompatibilitásának ellenőrzésében is alkalmazták. Sőt, az épületinformációs modellt a karbantartáshoz is felhasználják.

Az épület energetikai hatékonyságát passzív elemekkel is javították, így az üveghomlokzatoknak köszönhetően a földszinten és a másodikon a nyilvános terekben
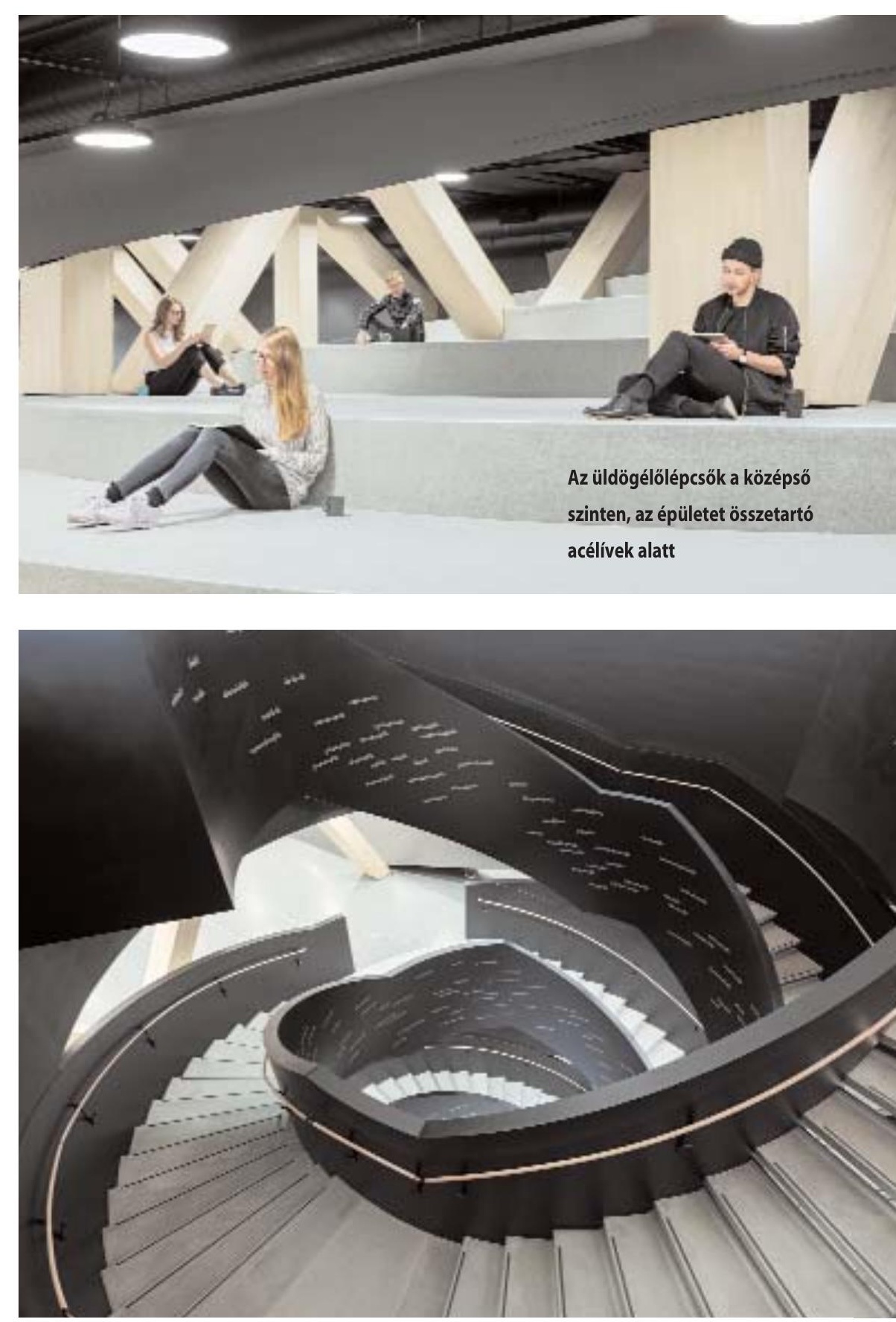

A lépcsők DNS-szerü kettős csavart alkotnak, a fekete 80 tonnás, mégis légiesnek tűnő acéllépcsőknek nincsenek külön tartóoszlopai, az épület szerkezeti elemei tartják meg őket

napközben főként természetes megvilágítást használnak. A tervezésnek köszönhetően a belső terek könnyedén átalakíthatók, ezt mindhárom szinten álpadló is segíti. Így a tervezett 150 éves élettartam alatt mód van az igényeknek megfelelő átalakításokra.

\section{Timaffy-Touko Lilla}

\section{Konyhatervezés: Saircon}

Modell: Klaus Stolt (pályázat),

Stoltmallit (megvalósulás)

Kivitelező: Kaaritaivutus

Kumpula Oy

Építési tanácsadó: Ramboll CM

Fotó: Tuomas Uusheimo,

Kuvio (Oodi) 


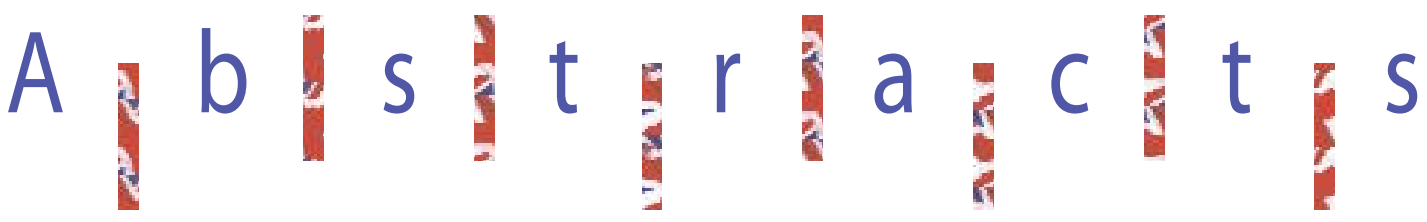

WESSELÉNYI-GARAY, Andor - EMRESZ, Adrienn: BUTTERY SHADE Citation: Metszet, Vol 10, № 4 (2019), pp 8-17, DOI: 10.33268/Met.2019.4.1

EIFFEL WORKSHOP IN THE RENOVATED NORTHERN VEHICLE REPAIR SHOP,

BUDAPEST, HUNGARY

ARCHITECT: MIKLÓS MAROSI

As industrial functions change their respective buildings often lay abandoned, as is the case for this Budapest rolling stock repair workshop, now operatic workshop. The spaces left behind no longer have the capacity to serve an industrial function, but the architecture suggests a grand potential. Why not restore the building to serve as a transport museum and Operatic Workshop. The spaces provided are perfect for both functions, social gathering and cultural identity.

\section{DEICHLER, Tímea: A COMMUNITY SPACE, WHERE ONE CAN ALSO READ}

\section{Citation: Metszet, Vol 10, № 4 (2019), pp 18-21, DOI: 10.33268/Met.2019.4.2}

ROTTENBERG LIBRARY, ROTTENBURG, GERMANY

ARCHITECTS: HARRIS and KURRLE ARCHITEKTEN

Digital storage of information has transformed how libraries function creating a new opportunity for communication across the generations. Older visitors may prefer to read books in relative silence whilst the younger might opt for digital entertainment, films, games and music. This library has been developed as a social, public space which caters to all tastes in information use described by its designers as a "third" type of space. The "first" being home, the "second" work and the "third" a social/cultural space. The reality being a building which functions as a home from home where one could also work towards building a better society.

\section{TIMAFFY-TOUKU, Lilla: ODE FROM THE LIBRARY}

Citation: Metszet, Vol 10, No 4 (2019), pp 22-27, DOI: 10.33268/Met.2019.4.3

LIBRARY OODI, HELSINKI, FINLAND

ARCHITECTS: ALA ARCHITECTS

Designed with longevity in mind, expected to last at least 150 years, this library com. plex is planned on three levels which have been made ready for future adaptations by means of suspended floors and ceilings separated by intelligent wall systems. Functioning as a conventional library, digital information hub, theatre space and temporary workshop this facility should be able to host 10 thousand people daily. Designed as a 100 metre long bridge, access to this building is possible from three important directions: the main railway station, parliament and thirdly a large urban square. The concept being to develop the Finnish culture for sharing information, meeting in public and creating almost residential scaled spaces.

\section{CSANADY, Păl: LESSONS FROM THIS YEAR'S MIES VAN DER ROHE AWARDS} Citation: Metszet, Vol 10, No 4 (2019), pp 28-31, DOI: 10.33268/Met.2019.4.4 TOWER BLOCK RENOVATION, GRAND PARC, BORDEAUX, FRANCE ARCHITECTS: LACATON, VASSAL, DRUOT and HUTIN

Taking a 1960s residential block and adding a two metre wide conservatory and 1 metre wide balcony to all floors has challenged the idea that the Mies Van Der Rohe Award is usually presented to elitist projects. This building had in previous years been renovated to allow for better thermal performance meaning the actual quality of life was not vastly improved. The addition of the new balconies and conservatory has allowed its occupants to have better quality of space, improved natural ventila- tion and better climatic control. Possibly establishing a guideline for how to renovate residential housing blocks.

\section{DÉNES, Eszter: THE SOUL OF THE CITY}

Citation: Metszet, Vol 10, № 4 (2019), pp 32-37, DOI: 10.33268/Met.2019.4.5 NEW LIBRARY, MAKÓ, HUNGARY

ARCHITECTS: IMRE MAKOVECZ and JUDIT GERENCSÉR SZENTE-VARGÁNÉ

Makó has already established itself as a city fitting the idea of "Makó for Makovecz" and finally the library envisioned by this master architect has been realised. Faithfully undertaken by architects who worked alongside him to complete this organic architectural entity. Adding to the fact that an estimated 40 thousand visitors come to visit this cultural centre. Architecture forming a strong part of this city's soul and character.

\section{WETTSTEIN, Domonkos: THE LAVENDER LEANNESS} Citation: Metszet, Vol 10, № 4 (2019), pp 38-41, DOI: 10.33268/Met.2019.4.6 CIVIC CENTRE, TIHANY, HUNGARY ARCHITECT: PÉTER VÉR

As tourism in the Balaton area develops so does the need for a greater diversity of attractions. During the last decade Tihany has established itself as a centre for lavender farming and the associated offshoot industries, dried flowers, perfume and food products to name a few. Here an existing building has been restored, adapting it to serve as place for "craft" manufacturing of beauty products, whilst handing over the roof space to the local government as office space.

\section{WARE-NAGY, Orsolya: PRIVATE-PROTECTION OF MONUMENTS} Citation: Metszet, Vol 10, No 4 (2019), pp 42-45, DOI: 10.33268/Met.2019.4.7 HARIS PARK at MARCZIBÁNYI SQUARE, BUDAPEST, HUNGARY ARCHITECTS: MÁRTON KOVÁCS and SÁNDOR GÖCSEI

Originally developed as the Member's Gun Club of Budapest and shooting range this somewhat romantically styled building has been through many reincarnations, none of them long lasting or very successful. Eventually the Haris family has taken hold of this unique opportunity to redevelop the German neo-Renaissance styled building and its grounds to create a new dining experience and social hub, knowing that the original architectural style of this place forms the key to its success. What makes this project unusual is the desire of a private investor to secure the cultural identity of a city's monumental building to secure a business vision.

\section{SÁGHI, Attila: RE. PURPOSE.}

\section{Citation: Metszet, Vol 10, № 4 (2019), pp 46-49, DOI: 10.33268/Met.2019.4.8} THE NEW AGE OF LISTED BUILDING RESTORATION

The current trend for restoration of historic buildings has many lessons for the architectural profession and public alike. The worst example being to leave a building to decay due to lack of function. Then come problems of bad use of space, followed by overloading a building with too many ideas or uses. The lesson being how to avoid these mistakes and generate a valid use for these buildings which respects their historic value, building fabric and contemporary use patterns. 